\title{
Farmers Influence on Plant Diversity Conservation in Traditional Cocoa Agroforestry Systems of Côte D'Ivoire
}

\author{
Boko Brou Bernard ${ }^{1}$, Koulibaly Annick ${ }^{2 *}$, Amon-Anoh Dénis Esdras ${ }^{3}$, Koffi Dramane Bakari ${ }^{4}$, \\ M'Bo Kakou Antoine Alban ${ }^{5}$, Porembski Stefan ${ }^{6}$ \\ 1,4, Université Jean Lorougnon Guédé, UFR Environnement, BP 150 Daloa, Côte d'Ivoire. \\ ${ }^{2,3}$ Université Jean Lorougnon Guédé, UFR Agroforesterie, BP 150 Daloa, Côte d'Ivoire. \\ ${ }^{5}$ World Agroforestry Centre, 08 BP 2823 Abidjan 08, Côte d'Ivoire. \\ ${ }^{6}$ University of Rostock, Institute of Biosciences, Department of Botany, Wismarsche Str,
} 44-45, D-18051 Rostock, Germany

*Corresponding Author: Koulibaly Annick, Université Jean Lorougnon Guédé, UFR Agroforesterie, BP 150 Daloa, Côte d'Tvoire.

\begin{abstract}
Côte d'Ivoire keeps the leading place of cocoa production in the world because of the rapid expansion of cocoa cultivation areas at the expense of forests. In order to contribute to adapting the management of cocoa plantations to global change, our study focused on the population structure of associated woody vegetation with reference to utilization. In the Doboua region, a floristic survey on 90 plots of $400 \mathrm{~m} 2$ each and ethnobotanical interviews of 180 producers help to better analyze future conservation of cocoa agroforestry systems. Floristic variability was closely related to three distinct structural levels of frequency and ecosystem services, by the multiple factorial analysis. The group of the most frequent species denominates several fruit and food providing species, medicinal plants and business activities. The group of moderately frequent species comprises shade trees for young cocoa trees, and timber species. The less frequent species, generally spontaneous plants, contribute to firewood provision. Thus, the ecosystem services concern distinct species and reflect the diversity through peasant's management. Sustainable management for conservation of traditional cocoa agroforestry systems requires global change to be taken into account, ensuring the resilience of the agricultural areas and food security.
\end{abstract}

Keywords: Agrosystems, Daloa, Ecosystem services, Global Change, Phytodiversity, Sustainable agriculture, West Africa

\section{INTRODUCTION}

Cultivation of trees in harmonious combination with crops is an old practice applied by farmers around the world. There are many examples of similar traditional practices in several parts of the world such as Central America (Wilken, 1977), Asia (Conklin, 1957), Finland (King, 1987) and Nigeria (Forde, 1937, Ojo, 1966). These examples are now referred to as "agroforestry" by Beer et al. (2003), AESA (2015) and Ngono et al. (2015). According to ICRAF (2013), agroforestry is the introduction of trees into cropping systems and their management to increase productivity, profitability, diversity and sustainability of the ecosystem. Agroforestry systems with cocoa (Theobroma cacao L.) are popular in West and Central Africa (Sonwa et al., 2003; Koulibaly, 2008) because they can reduce deforestation in the tropics (Dixon et al., 2001). In fact, during cocoa cultivation, cocoa trees are associated to many perennial woody forest and fruit species, which provide farmers with different products that they consume or sell to increase their income (Herzog \& Gotsch, 1998, Duguma et al., 2001; Asare, 2005; Sonwa et al., 2007; Temgoua et al., 2018, Koulibaly et al., 2010a)

Since 1978, Côte d'Ivoire has become the world's leading producer and exporter of cocoa beans by providing over 42\% of the world supply (Braudeau, 1969; Tano, 2012, MINEF, 2015; ICCO 2017, M'Bo et al., 2019,). Cocoa cultivation procures around 30\% of the worldwide income from exports (MINEF 2015) and contributes to more than 15\% of Côte d'Ivoire's Gross Domestic Product (ICCO, 2017). Cocoa production keeps over one million farmers occupied, standing for $15 \%$ of the rural 
population, because $80 \%$ of cocoa are produced by smallholders (Jouvé and Milly, 1990; Koulibaly et al., 2010b; Assiri et al., 2012). However, the expansion of cocoa plantations leads to land conversion with drastic changes in vegetation cover and biodiversity (Chatelain et al., 1996; Koulibaly, 2008; Goetze et al., 2010; Aké-Assi and Dian (1990); FAO, 2005, 2009). The current land cover of Côte d'Ivoire indicates that more than $30 \%$ of the territory is occupied by cocoa plantations (FAO, 2009; REDD+ Strategy, 2018; Anonymous 2018; World Bank, 2019). In the context of global change, Côte d'Ivoire counteracts this forest loss by promoting agroforestry activities. The goal is to encourage farmers to maintain and introduce tree species in their cocoa plantations, while the effects of cocoa cultivation on plant diversity are hardly known.

This concern was met first with scientific investigations of forests in cocoa regions that have shown a severe reduction of the specific richness of forests by logging in the past (Koulibaly, 2008, Goetze et al., 2010). As a consequence, regeneration of forest species is compromised by an absence of adult or juvenile plants (Koulibaly et al., 2016). Concerning the cocoa plantations, floristic richness is highest in the early years in the South, Centre and West of Côte d'Ivoire (Adou Yao \& N'guessan, 2006; Koulibaly, 2008; Konan et al., 2011). The most critical phase during the development of a cocoa plantation, which leads to a severe reduction in woody vegetation, is estimated to happen between the ages of 6 and 20 years of a plantation (Koulibaly, 2008). A decrease of important native plants in cocoa plantations was reported by several authors, being a result of influences from farmers regarding their origin, age and needs (Koulibaly, 2008, Piba et al., 2011; Kpangui et al., 2015: Koulibaly et al, 2015). However, most works studied only briefly the diversity of vegetation structure associated with cocoa trees although this information can help estimating the potential conservation of cocoa agroforestry systems (Deheuvels et al., 2007b; Veech et al., 2002; Crist et al., 2003).

As the presence of a species is linked to the preferences of the producers, we hypothesize that a species is encountered in the agrosystem once it is preferred, and that the species' frequency is high. It follows that the most adapted structural parameter is the specific frequency, allowing to estimate level of the peasants' conservation of species associated with cocoa plantations. In order to contribute to adapting the management of cocoa plantations to global change, our study focuses on the population structure of associated woody vegetation with reference to ecosystem services. Our study was carried out in the Doboua area (Figure 1), located in the second largest cocoa production region of Côte d'Ivoire (Esso, 2009).

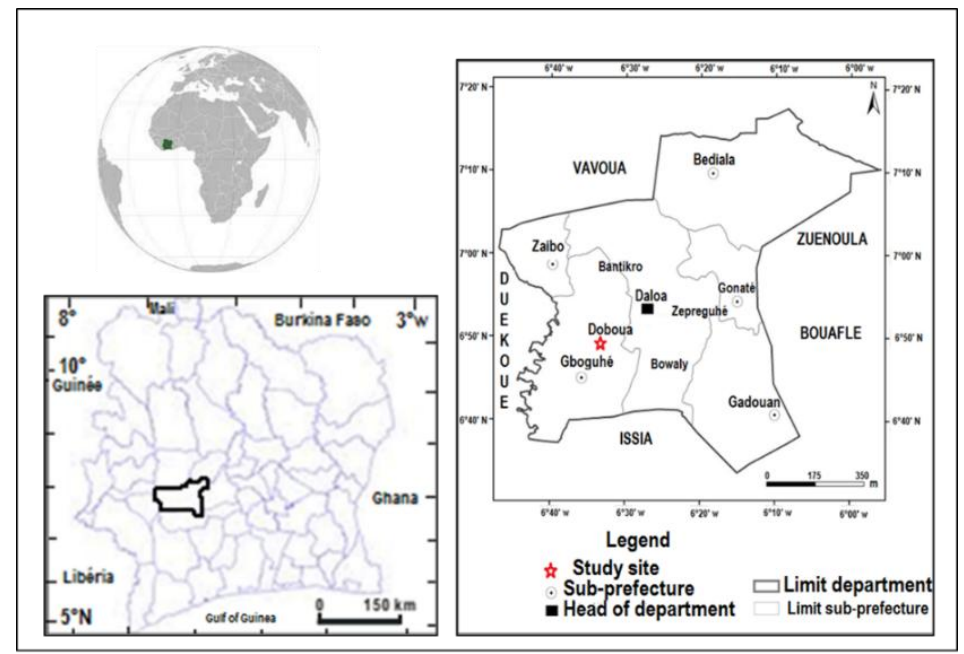

Figure 1: Location of the study site in Côte d'Ivoire.

\section{Material AND Methods}

\subsection{Description of the Study Site}

The Doboua area is located in the western forest region of Côte d'Ivoire, dominated by semi-deciduous dense forests. Annual rainfall is around $1100 \mathrm{~mm}$ (Eldin, 1971; Declert, 1997, Anonyme, 2017). Temperatures range from $29{ }^{\circ} \mathrm{C}$ to $30.8{ }^{\circ} \mathrm{C}$ with an average of $29.67{ }^{\circ} \mathrm{C}$. The landscape is formed by flat, slightly undulating areas bordering the Sassandra River (Koffié-bikpo \& Kra 2013). Soils are 

D'Ivoire

granitic and have a good ability for cultivating several crop types (Perraud, 1971; Lecomte, 1990). This situation has led to the development of perennial crops (cocoa, coffee, oil palm), food crops, and fallow lands, under anthropogenic pressure (Koffié-bikpo \& Kra, 2013)

\subsection{Data Collection and Analysis}

The characteristics of associated woody vegetation were assessed in a floristic survey within 90 plots of $400 \mathrm{~m}^{2}$ each. Diversity was determined through the number of species in floristic categories such as families, life forms and chorology. The generic coefficient of the flora was calculated according to Aké Assi (1984), which is the ratio between the total number of genera and the number of species belonging to them, as a percentage. High values of this coefficient indicate a diverse flora. Ethnobotanical interviews with 180 producers in the study area allowed for compiling the uses of woody species associated with cocoa plantations.

Firstly, structure was described by defining proportions of woody plants between floristic categories, which were assessed through the number (or mean) of individuals and the analysis of variance with one factor, testing the significance between categories. Secondly, the factorial correspondence analysis was used to describe the distribution of species frequency, and then its combination with an hierarchical linkage cluster analysis using Euclidean distance classified preferred species into different groups. Indicator species of each group was identified. Thirdly, multiple factorial analysis was used to describe floristic variability under ecosystem services in each group. All statistics were done with R 4.0 software.

\section{Results}

\subsection{Floristic Characteristics}

\subsubsection{Floristic Composition}

The list of species found in the 90 plots shows 59 species assigned to 51 genera and 25 families. The generic coefficient of 0.86 indicates that the Doboua cocoa area contains a rich flora, and the most dominant (sub)families are Euphorbiaceae, Moraceae and Sterculiaceae with $10 \%$ of all species (Figure 2), followed by Anacardiaceae, Mimo"sac"eae, Rutaceae and Caesalpiniaceae, comprising 7\% of the species. The species are grouped under four biological types dominated by microphanerophytes (83.68\%, Figure 3A). Regarding the chorological distribution, $61.98 \%$ of all species belong to the transition zone between the Guinéo-Congolian and the Sudano-Zambezian domain (GC-SZ), and $16.24 \%$ are introduced species (Figure 4A).

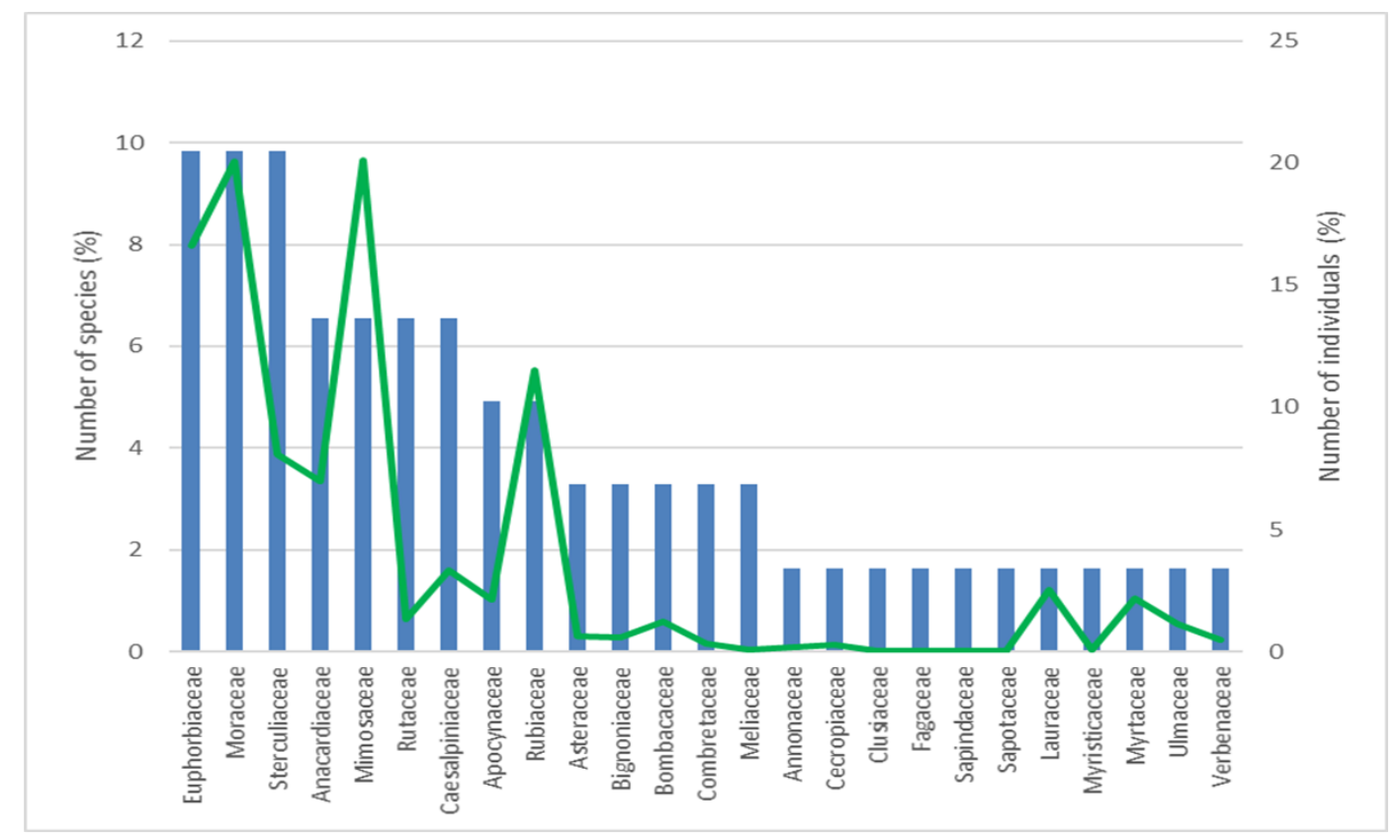

Figure 2: Proportionate numbers of species (blue) and individuals (green) in family taxa of 90 plots of cacao plantations. 


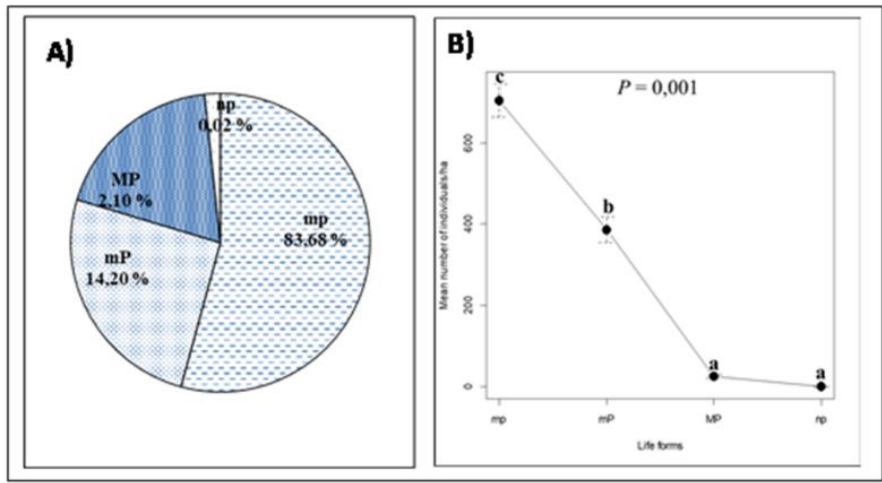

Figure 3: Life forms in 90 cacao plantations. A) Proportionate number of species; B) Mean number of individuals. $\mathrm{mp}=$ microphanerophytes, $\mathrm{mP}=$ mesophanerophytes, $\mathrm{MP}=$ mégaphanerophytes, $\mathrm{np}=$ nanophanerophytes.
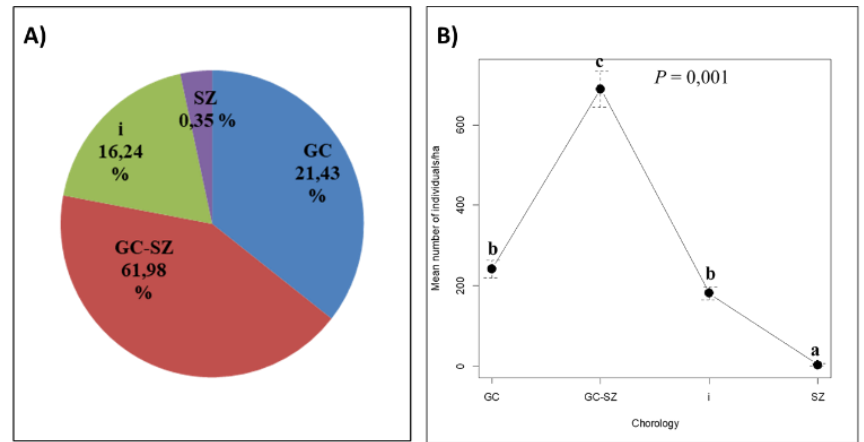

Figure 4: Chorology in 90 cacao plantations. A) Proportionate number of species; B) Mean number of individuals. GC = Guinéo-Congolian, GC-SZ = Guinéo-Congolian /Sudano-Zambezian transition, SZ = Sudano-Zambezian, i= introduced

\subsubsection{Importance of Woody Vegetation for Farmers' Life}

The interviews revealed that the species maintained in traditional cocoa agroforestry systems are useful in several domains of farmers' life (Figure 5). Most of them were used preferentially to produce shade at the young cocoa tree $(44.1 \%)$, followed by the supply of firewood $(37.3 \%)$ and medicinal use (35.6\%). The smallest numbers of plants were used for farm delimitation (11.9\%) and soil fertilization $(6.8 \%)$.

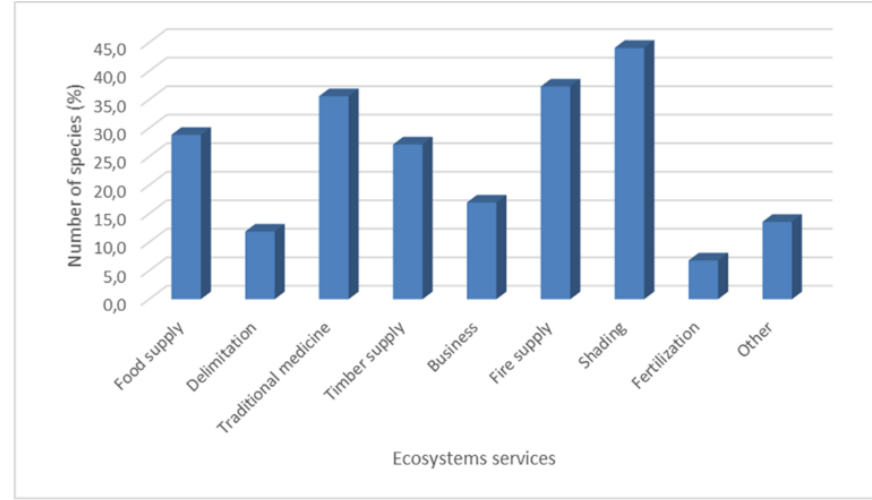

Figure 5: Importance of main ecosystem services of associated woody species in traditional cocoa agroforestry system of Doboua zone

\subsection{Structural Components of Woody Vegetation}

\subsubsection{Proportions in Floristic Categories}

The distribution of individuals across families shows that the families containing most species present also the largest number of individuals. These are, in decreasing order, Mimosaceae (20.11\%), Moraceae (20.06\%) and Euphorbiaceae (16.63\%, Figure 2). Concerning life forms, the average number of individuals was highest for microphanerophytes. This number varies significantly between life forms (ANOVA test, $\mathrm{F}=172.8 ; \mathrm{P}=0.001$, Figure $3 \mathrm{~B}$ ). In terms of chorology distribution, individuals 
Farmers Influence on Plant Diversity Conservation in Traditional Cocoa Agroforestry Systems of Côte D'Ivoire

belonging to species that have an affinity to the GC-SZ transition zone were most numerous. Also, a significant difference becomes obvious when passing from one chorological affinity to another (ANOVA test, $\mathrm{F}=122.4 ; \mathrm{P}=0.001$, Figure $4 \mathrm{~B}$ ).

\subsubsection{Species Frequency in Cocoa Plantations}

The factorial correspondence analysis (Figure 6) showed that the first and second axes account for $74.27 \%$ of variability of the analyzed database (Table 1). Following axis 2, species were grouped according to their frequency in traditional cocoa agroforestry systems. Three species groups were identified. This result illustrates the structure levels of species (groups) preserved in traditional cocoa agroforestry systems.

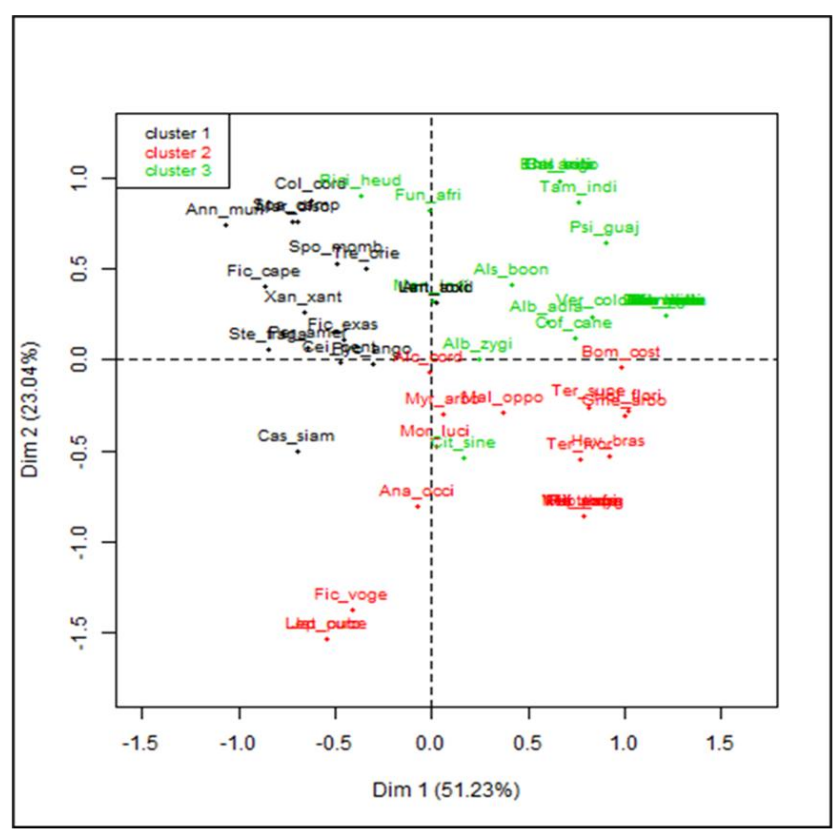

Figure 6: Factorial correspondence analysis of associated woody species individuals according to their frequency in 90 plots of cacao plantations.

Table1. Summary of FCA of species in cocoa agroforestry systems of the Doboua area. Dim.1-Dim.4: FCA axes.

\begin{tabular}{cccccc}
\hline Axes & Dim.1 & Dim. 2 & Dim. 3 & Dim. 4 & Total inertia \\
& $(\%)$ & $(\%)$ & $(\%)$ & $\begin{array}{c}\text { T }) \\
(\%)\end{array}$ \\
\hline Variance & 0.307 & 0.138 & 0.099 & 0.055 & 0.599 \\
Floristic variability & 51.231 & 23.040 & 16.558 & 9.172 & 0.828 \\
Cumulative values of floristic variability & 51.231 & 74.270 & 90.828 & 100 & \\
\hline
\end{tabular}

These groups are each characterized by an indicator species finding by the Indval method: group (G1) with Annona muricata, group (G2) with Ficus vogelii and group (G3) with Psidium guajava (Figure 7).

Group (G1) with Annona muricata contains less frequent species that were mostly spontaneous fruit and forest species such as Spondias mombin, Annona muricata, Lannea acida, Blighia welwitschii, Newbouldia laevis, Daniellia ogea, Sterculia tragacantha, Ficus exasperata, and Myrianthus arboreus. This group also contains large trees such as Ceiba pentandra, Cola cordifolia, Antiaris toxicaria and Entandrophragma angolense.

In group (G2) with Ficus vogelii, there are moderately frequent species, including cultivated arborescent species such as Anacardium occidentale, Hevea brasiliensis and Gmelina arborea, and preserved forest species like Terminalia ivorensis, Terminalia superba, Ficus vogelii, Mallotus oppositifolius, Morinda lucida, Bombax costatum, Nauclea diderrichii and Milicia excelsa.

Group (G3) with Psidium guajava conains the most frequent species. These were mainly fruit cultivated species like Psidium guajava, Citrus sinensis, Citrus maxima, Coffea canephora, Citrus limon, Citrus maxima, Jatropha curcas and Persea americana, Castanea sativa, Garcinia kola and Tamarindus indica. There were also characteristic shrub species generally found in secondary formations, such as 
Farmers Influence on Plant Diversity Conservation in Traditional Cocoa Agroforestry Systems of Côte D'Ivoire

Albizia adianthifolia, Albizia zygia, and large forest species like Spathodea campanulata, Pycnanthus angolensis, Funtumia africana, Vernonia colorata, Vernonia amygdalina, Ricinodendron heudelotii, Alstonia boonei and Nesogordonia papaverifera.

\subsubsection{Plant Group Characteristics}

Group G3 with Psidium guajava contains the highest number of species (55.14\%), however, specific richness is not significantly different between groups (ANOVA test, $\mathrm{F}=2.457 ; \mathrm{P}=0.0916$, Table 2). Concerning the Shannon Diversity Index, groups G1, G2 and G3 appeared to be little diversified, with values $\mathrm{H}=1.71( \pm 0.32) ; \mathrm{H}=1.57( \pm 0.3)$ and $\mathrm{H}=1.69( \pm 0.33)$, respectively, also did not show significant differences (ANOVA test, $\mathrm{F}=0.976 ; \mathrm{P}=0.381$ ). The Pielou equitability index is relatively high in all groups, ranging from $\mathrm{E}=0.84$ to $\mathrm{E}=0.88$, and does not express any significant difference between the groups (ANOVA test, $\mathrm{F}=1.705 ; \mathrm{P}=0.188$ ).

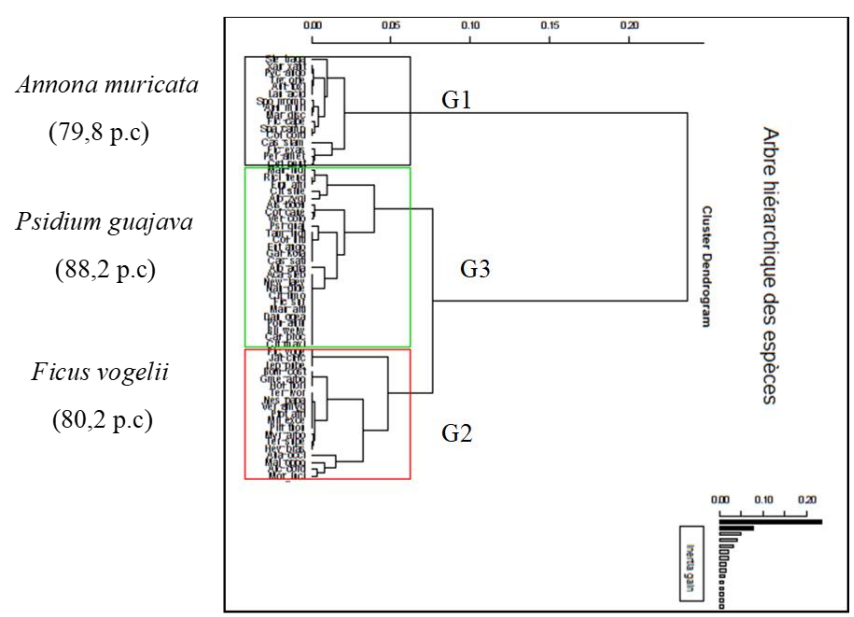

Figure 7 : Indicator species of each group of frequency level in a hierarchical classification of associated woody species individuals in 90 plots of cacao plantations.

Table2. Floristic characteristics of groups of species frequency from different plant groups from cocoa plantations in the Doboua area; $\alpha=0.05$; H : Shannon index; E : Piélou equitability.

\begin{tabular}{|c|c|c|c|c|}
\hline $\begin{array}{c}\text { Grou } \\
\text { ps }\end{array}$ & $\begin{array}{c}\text { Number of } \\
\text { species }\end{array}$ & $\begin{array}{l}H \text { (mean) value/ } \\
\text { plot) }\end{array}$ & $\begin{array}{c}E \text { (mean) value/ } \\
\text { plot) }\end{array}$ & $\begin{array}{c}\text { Indicator species (\% value compared to } \\
\text { other species) }\end{array}$ \\
\hline G1 & 29 & $1.71 \pm 0.32^{\mathrm{a}}$ & $0.86 \pm 0.074^{\mathrm{a}}$ & Annona muricata (79.8) \\
\hline $\mathrm{G} 2$ & 19 & $1.57 \pm 0.3^{\mathrm{a}}$ & $0.88 \pm 0.083^{\mathrm{a}}$ & Ficus vogelii $(80.2)$ \\
\hline G3 & 59 & $1.69 \pm 0.35^{\mathrm{a}}$ & $0.84 \pm 0.079^{\mathrm{a}}$ & Psidium guajava (88.2) \\
\hline \multicolumn{2}{|c|}{ Tests ANOVA } & $\begin{array}{c}F=0.976 ; P= \\
0.381\end{array}$ & $\begin{array}{c}F=1.705 ; P= \\
0.188\end{array}$ & \\
\hline
\end{tabular}

\subsection{Floristic Variability Related to Ecosystem Services}

A multivariate factorial analysis in Figure 8 showed that the species and the ecosystem services are overlapping and distributed on the plot quadrants as vectors showing floristic variability among services for each frequency level of conservation. Each quadrant also indicated the association of frequency with the different ecosystem services. Most frequent species were used in the domains of business, food supply and traditional medicine. It was about the sale of numerous fruits from species like Coffea canephora, Ricinodendron heudelotii, Cola nitida, Persea americana, Citrus sp. and Psidium guajava. The plants from these species were concern by food supply, like Castanea sativa and Tamarindus indica, and medicine such as Vernonia sp., Pycnanthus angolensis and Alstonia boonei. Plant species used for shading of plantation were major timber supply. These plants were for example Milicia excelsa, Terminalia ivoriensis, Terminalia superba and Piptadeniastrum africanum. These species were moderately frequent in the agrosystems because they were the biggest forest species usually preserved directly after the cut of the forest. The less frequent species serve as firewood supply, such as Mallotus oppositifolius and Holarrhena floribunda; and other ecosystem services like fertilization with Gmelina arborea and for delimitation with Hevea brasiliensis. 

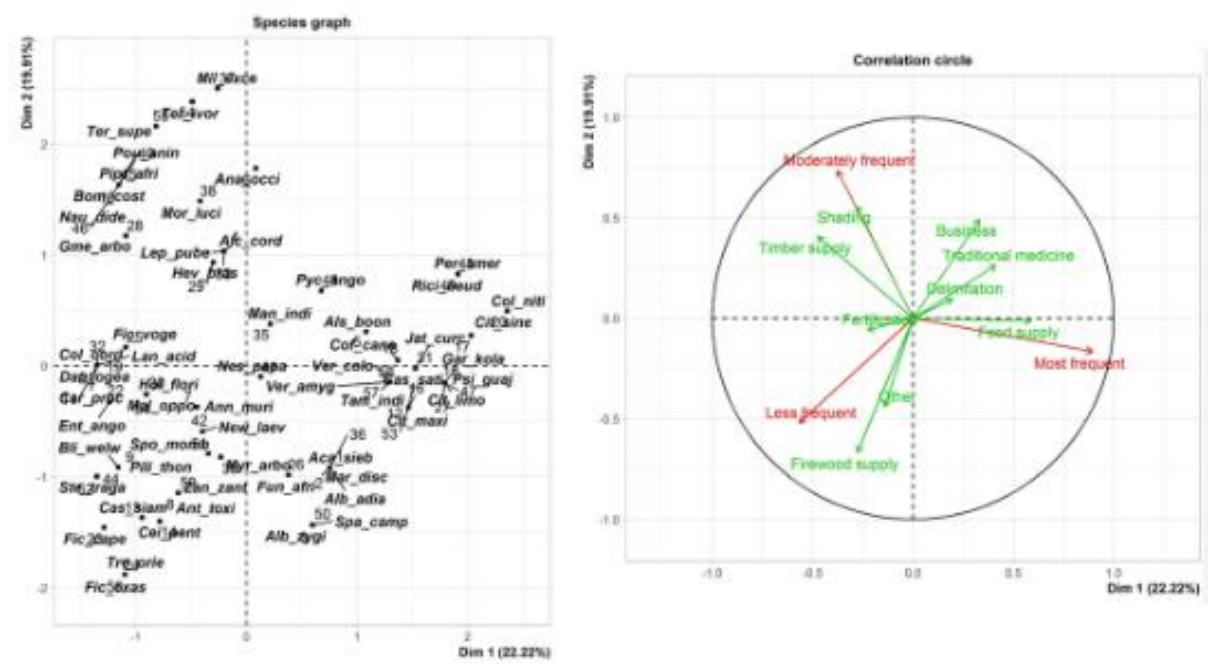

Figure 8: Main ecosystem services of associated woody species related to their frequency in 90 plots of traditional cacao plantations.

\section{DISCUSSION}

\subsection{Phytodiversity of Traditional Cocoa Agroforestry Systems}

Woody vegetation associated with cocoa trees had a rich flora, which contains 59 species belonging to 51 genera distributed among 25 families. The number of species obtained in the study area is much higher than in the M'Brimbo region, in a forest-savanna transition zone that only 14 woody species were associated to (Gala Bi et al., 2017). It is also higher than the associated flora in plantations of different ages in Cameroon with mean values ranging from 24 to 46 species (Temgoua et al., 2018). The average number of associated species is close to that obtained by Koulibaly (2008) in the Lamto region, CentralSouth of Côte d'Ivoire, being wetter than our study area. Introduction and preservation of more species in plantations has been reported by several authors including Tondoh et al. (2015) and Koulibaly (2008) in Côte d'Ivoire, (Asare, 2005) in Ghana, (Oke and Odebiyi, 2007) in Nigeria, (Zapfack et al., 2002; Sonwa et al., 2007) in Cameroon. Plant diversity analysis revealed that natural and exotic species were preserved in cocoa agrosystems. Seven most dominant families were Euphorbiaceae, Moraceae, Sterculiaceae, Anacardiaceae, Mimosaceae, Rutaceae and Caesalpiniaceae. In cocoa agrosystems, Euphorbiaceae and Moraceae were also found dominant by Konan et al. (2011) as well as Sterculiaceae in central-western Côte d'Ivoire by Kouadio (2018). Among the seven families identified to be dominant in cocoa agrosystems in Cameroon by Temgoua et al. (2018), the families of Sterculiaceae and Fabaceae (and Caesalpiniaceae) were cited. Dominant families were similar in the large band of traditional cocoa agroforestry systems in the West Africa. The most represented life forms in terms of species number were microphanerophytes $(83.68 \%)$. This dominance of microphanerophytes is thought to be due to their perennial life form with vegetative resprouting, which constitutes the quantitatively important regeneration mode in the cocoa agrosystems as reported in the Lamto Reserve region and Oumé department (Piba, 2011; Koulibaly et al., 2016). This highest number of individuals in this life form could cause ecological disturbance and lead to a decrease of the number of chamaephyte and therophyte species (Kokou and Caballé, 2000; Vroh, 2013). The flora of the Doboua area had a pronounced affinity to the transition zone between the Guineo-Congolian and the Sudano-Zambezian domains $(61,98 \%)$. This result is contrary to Koulibaly (2008) and Diomandé (2018) who also worked in the cocoa agrosystems in the Lamto Reserve region and Djêkro area in the Guineo-Congolian transition zone, where they reported a dominance of Guineo-Congolian species. This difference could be due to the fact that these areas were in a zone of pronounced humidity.

\subsection{Diversity Conservation and Sustainable Cocoa Cultivation}

The distribution of individuals across the floristic categories reflects the producer's preference for certain species which thus become more represented in number of individuals. Analysis of the structure of vegetation associated with cocoa trees in the cocoa agrosystems has shown that microphanerophytes are favoured both in terms of number of species and number of individuals. This is similar in species that have a strong affinity for the GC-SZ transition zone. The producer's preferences change the 
structural characteristics of the studied agrosystems. The component factorial analysis has made a notable distinction between three levels of change. Through the frequency levels, associated species were grouped into: less frequent species, moderately frequent species and most frequent species. These groups have a weak index of Shannon diversity and are thus found to be little diversified, while the Pielou index indicates that individuals were distributed with equitability among the groups. Management of associated woody species is fragile even if a certain homogeneity of the environment reflects a reasonable arrangement by farmers with regard to the benefit of making maximum profits (Temgoua et al., 2018). This result is similar to those of Oke and Odebiyi (2007) in Nigeria, and Asare and Tetteh (2010) in Ghana in the cocoa agroforestry systems.

Traditional preservation was assessed using a multiple factorial analysis to describe the floristic variability according to the ecosystem services. The most frequent species are used for food supply, traditional medicine and provide marketable products including fruits that sell well on local and regional markets (Sonwa et al., 2007). Moderately frequent species play a protective role against sun radiation for young cocoa plants and thus contribute to their optimal growth (Cissé et al., 2016). Subsequently, they are eliminated for selling timber wood (Koulibaly et al., 2016). The less frequent species ensure the permanent supply of firewood and various other goods. These species were mostly spontaneous species that develop by sprouts or seeds left in the soil (Koulibaly, 2008). Other more or less frequent species are protected or introduced to serve as delimitation tree in the plantation such as Hevea brasiliensis and/or contribute to improve the fertility of the soil such as Gmelina arborea and Ficus vogelii. These latter species are used to protect the soil until sufficient cover is provided by the cocoa tree itself (Braudeau, 1969; Cissé et al. 2016). This method of plantation management applied in our study area is similar to that used in Cameroon where farmers keep the cocoa trees under woody trees of different age classes (Sonwa et al., 2000), and in Burkina Faso, where farmers use fallows as a method for restoring soil fertility to help managing agrosystems (Yaméogo, 2009). The results of this study show that each ecosystem service concern specific species, which ensures diversity achieved and supported by farmers.

Also, six species of particular status ranging from vulnerable to threatened by extinction have been noted in the studied cocoa agrosystems. It was Entandrophragma angolense reported among the less frequent species. In the group of moderately frequent species Nauclea diderrichii and Terminalia ivorensis were found. Milicia excelsa, an endemic species of Côte d'Ivoire, is threatened by extinction. Garcinia kola et Nesogordonia papaverifera were noted among most frequent species. To species of particular status, endemic or threatened by extinction, conservation efforts should be given priority (Myers et al., 2000).

\section{CONCLUSION}

The cocoa farmer is the main actor in cocoa agrosystem creation. His contribution to conserving plant diversity is visible through the species frequency in the cocoa agrosystems. The three levels of species frequency contribute differently to the multiple gains, across different ecosystem services, and allow to understand the farmer's strategies to ensure the plant diversity conservation. Our study contributes to a better knowledge on the flora of woody species associated with cocoa trees, but above all allows us to evaluate the potential conservation of traditional cocoa agroforestry systems. In these systems, the flora is rich and contains mostly shrubs well adapted to the conditions. Vulnerable species have found a refuge and are generally frequent in cocoa agrosystems. The large trees preserved in the plantations for a long time contribute to the additional income of the farmer through the supply of timber and marketable products. In search for a compromise between cocoa production and plant diversity conservation, account must be taken of global change by ensuring the resilience of agricultural environments. In fact, in the cocoa regions of Côte d'Ivoire the majority of the species are rare in remnant forest formations, most of which are degraded.

\section{ACKNOWLEDGEMENT}

The authors would like to thank all the farmers from the Doboua area, the responsibles of cooperatives in the Daloa region for facilities and welcoming, and Dr Goetze Dethardt from University of Rostock, for the relevant translation 


\section{REFERENCES}

[1] Wilken G. C., Integrating forest and small-scale farm systems in Middle America, Agroecosystems. (3), 11 (1977).

[2] Conklin H. C., Hanundo Agriculture. FAO, Rome, Italy, 1957.

[3] King K. F. S., The history of agroforestry. In: Steppler H. A and Nair P. K. R, ed.

[4] Agroforestry: A Decade of Development, ICRAF, Nairobi, Kenya, 1987, pp. 1-11.

[5] Forde D. C., Land and labor in a Cross-River village, Geographical Journal. Volume XC. N${ }^{\circ}$, (1937).

[6] Ojo G. J. A., Yoruba Culture, University of Ife and London Press, London, UK, (1966).

[7] Beer J., Harvey C., Ibrahim M., Harmand J. M., Somarriba E. and Jimenez F., Environmental services of agroforestry systems, Agroforestería en las Américas. 1(10), 7 (2003).

[8] AESA EAST AFRICA LTD, Training Manual on Agroforestry, Nairobi, Kenya, 108 (2015).

[9] Ngono F., Mala A.W., Levang P., Ambang Z., Evolution des systèmes agroforestiers cacao et impact environnemental à Mbangassina : cas du village Talba, Revue Scientifque et Technique Forêt et Environnement du Bassin du Congo. (5), 5 (2015).

[10] ICRAF., Research program on Climate change, Agriculture and food security, Technical report, 59 (2013).

[11] Sonwa D. J., Weise S. F., Ndoye O. and Janssens M. J. J., The promotion of cocoa agroforest in west and Central Africa, Voluntary paper during the XII world Forestry Congress on Forests, Source of life, Quebec city, 8 (2003).

[12] Koulibaly A., Caractéristiques de la végétation et dynamique de la régénération, sous l'influence de l'utilisation des terres, dans des mosaïques forêts-savanes, des régions de la Réserve de Lamto et du Parc National de la Comoé, en Côte d'Ivoire. Thèse de doctorat, Biosciences, Université de Cocody (Abidjan, Côte d'Ivoire). pp. 151 (2008).

[13] Dixon J., Gulliver A. and Gibbon D., Farming Systems and Poverty, Improving farmers livehoods in a changing world, Rome, Italie, Fao, 413 (2001).

[14] Herzog F. \& Gotsch N., Assessing the sustainability of smallholder tree crop production in the tropics: a methodological outline, Journal of Sustainable Agriculture. (11), 24 (1998).

[15] Duguma B., Gockowski J. and Bakala J., Smallholder Cacao (Theobroma cacao Linn.) cultivation in agroforestry systems of West and Central Africa: challenges and opportunities, Agroforestry Systems. (51), 11 (2001).

[16] Asare R., Cocoa agroforests in West Africa, A look at activities on preferred trees in the farming systems, Ed. Forest and Landscape, Denmark, 89 (2005).

[17] Sonwa D. J., Nkongmeneck B. A., Weise S. F., Tchatat M., Adesina A. A. and Janssens M. J. J., Diversity of plants in cocoa agroforests in the humid forest zone of Cameroon, Biodiversity and Conservation. (16), 15 (2007).

[18] Temgoua L. F., Dongmo W., Nguimdo V. et Nguena C., Diversité Ligneuse et Stock de Carbone des Systèmes Agroforestiers à base de Cacaoyers à l'Est Cameroun : Cas de la Forêt d'Enseignement et de Recherche de l'Université de Dschang, Journal of Applied Biosciences. (122), 12 (2018).

[19] Koulibaly A., Traoré D et Goetze D., Le cacao et la diversité végétale. In: Konaté S, Kampmann D, (Eds). Biodiversity Atlas of West Africa, Tome III: Côte d'Ivoire. Abidjan \& Francfurt/Main, pp 418 - 425, (2010a).

[20] Braudeau J., Le cacaoyer, Collection Techniques agricoles et productions tropicales, Paris, France, Maisonneuve et Larose, 304 (1969).

[21] Tano M. A., Crise cacaoyère et stratégies des producteurs de la sous-préfecture de Méadji au Sud-ouest ivoirien. Thèse de Doctorat, Université Toulouse le Mirail-Toulouse II. France. pp. 263 (2012).

[22] Ministère de l'Economie et des Finances (MINEF)., Rapport annuel des statistiques économiques 2015, Ed novembre 2015, Direction de la documentation et de l'informatique, 110 (2015).

[23] ICCO., Annual report 2016-2017, Rapport final, Londres, 42 (2017).

[24] M'Bo K. A., Kouassi A., Amani K., Degrande A., Bayala J. et Kouame C., Recommandations adaptées au climat pour les régions cacaoyères de la Côte d'Ivoire : Etude en vue de développer un programme de formation sur les meilleures pratiques en matière de production cacaoyère tenant compte du climat en Côte d'Ivoire, Rapport World Agroforestry, ICRAF West and Central Africa Regional Programme, 84 (2019).

[25] Jouvé P. et Milly H., Compétitivité du cacao africain, Rapport d'étude, Ministère de la coopération et du développement, Paris, France, 279 (1990). 
[26] Koulibaly, A., Goetze, D., Porembski, S., Traoré, D. \& Aké-Assi, L. Vegetation characteristics and changes under cash crop cultivation in forest-savanna mosaics in Côte d'Ivoire. In: X. van der Burgt, J. van der Maesen \& J.-M. Onana (eds), Systematics and Conservation of African Plants, Royal Botanic Gardens, Kew, pp. 805-814. (2010b).

[27] Assiri A. A., Kacou E. A., Assi F. A., Ekra K. S., Dji K. F., Couloud J. Y. et Yapo A. R., Rentabilité économique des techniques de réhabilitation et de replantation des vieux vergers de cacaoyers (Theobroma cacao L.) en Côte d'Ivoire, Journal of Animal \& Plant Sciences. 14(2), 12 (2012).

[28] Chatelain C., Gautier L. and Spichiger R., A recent history of forest fragmentation in southwestern Ivory Coast, Biodiversity and Conservation. (5), 16 (1996).

[29] Goetze D., Koulibaly A., Porembski S. et Traoré D., La dynamique récente de la végétation. In : S. Konaté \& Kampmann D. (eds). Atlas de la Biodiversité de l'Afrique de l'Ouest, Tome III : Côte d'Ivoire. Abidjan \& Frankfurt/Main, Pp 377 - 384 (2010).

[30] Aké Assi L. et Dian B., Développement agricole et protection de la forêt : quel avenir pour la forêt ivoirienne ? Mitt. Inst. All.Bot. Hamburg. Band. (23), 7 (1990).

[31] FAO., Evaluation des ressources forestières mondiales, progrès vers la gestion forestière durable : Rome, Italie, 40 (2005).

[32] FAO., Harmonized world soil database (HWSD), Rome, Italy, 38 (2009).

[33] Stratégie Nationale REDD+., Rapport dénommé production durable de cacao en Côte d'Ivoire : besoins et solutions de financement pour les petits producteurs, Abidjan, Côte d'Ivoire, 48 (2018).

[34] Anonymous 2018 ., Réunion du Conseil Présidentiel du jeudi 17 Mai 2018, au Palais de la Présidence de la République de Côte d'Ivoire sur la Politique forestière. Le Ministre des Eaux et Forêts, M. Alain Richard Donwanhi a souligné que la Côte d'Ivoire qui, en 1960, disposait de 16 millions d'hectares de forêt, n'en dispose plus que de 3,4 millions aujourd'hui. Mis en ligne par la rédaction Connexion ivoirienne.net le 17 Mai 2018. Consulté le 18 octobre 2018.

[35] Banque mondiale., Situation économique en Côte d'Ivoire, Banque Mondiale, Abidjan, Côte d'Ivoire, worldbank.org/curated, 61 (2019).

[36] Koulibaly A., Kouamé D, Groga N., Kouassi Kouassi Etienne, Bakayoko Adama et Porembski stefan. Floristic characteristics of the mosaic and how forest progress on savanna in the Lamto Reserve region (Côte d'Ivoire)? International Journal of Development Research, 6 (05) 7, (2016).

[37] Adou Yao C. Y. \& N'Guessan E. K. (2006). Diversité floristique spontanée des plantations de café et de cacao dans la forêt classée de Monogaga, Côte d'Ivoire, Schweizerische Zeitschrift für Forstwessen. 157 (2), 5 (2006).

[38] Konan D., Goetze D., Koulibaly A., Porembski S. et Traoré D., Etude comparative de la flore ligneuse des plantations de cacao en fonction de l'âge et des groupes ethniques dans le Centre-Ouest de la Côte d'Ivoire, Annales de botanique de l'Afrique de l'Ouest. (07), 20 (2011).

[39] Piba S. C., Koulibaly A., Goetze D., Porembski S. et Traore D., Diversité et importance sociale des espèces médicinales conservées dans les agrosystèmes cacaoyers au Centre-Ouest de la Côte d'Ivoire, Annexe botanique Afrique de l'Ouest. (07), 16 (2011).

[40] Kpangui K. B., Kouamé D., Goné Bi Z. B., Vroh B. T. A., Koffi B. J. C., Adou Yao C. Y., Typology of cocoa-based agroforestry systems in a forest-savannah transition zone: case study of Kokumbo (Centre, Côte d'Ivoire), International Journal of Agronomy and Agricultural Research (IJAAR). 6(3), 11 (2015).

[41] Koulibaly A., Amon A. D. E., Konan D., Goetze D. and Traoré K., Evaluation of the impact of the "clearing practice" on vegetation for sustainable cacao culture in Côte d'Ivoire, International Journal of Science and Research (IJSR). 6(1), 7 (2015).

[42] Deheuvels O., Dubois A., Avelino J., Malézieux E., Agricultural practices and biodiversity in cocoa production landscapes. In: Second International Symposium on Multi-Strata agroforestry systems with perennial crops: Making ecosystem services count for farmers, consumers and the environment, Turrialba, Costa Rica, (2007b).

[43] Veech J. A., Summerville K. S., Crist T. O., and Gering J. C., The Additive Partitioning of Species Diversity: Recent Revival of an Old Idea, Oikos. 99 (1), 6 (2002).

[44] Crist T. O., Veech J. A., Gering J. C. and Summerville K. S., Partitioning Species Diversity across Landscapes and Regions: A Hierarchical Analysis of $\alpha, \beta$, and y Diversity, The American Naturalist. 162 (6), 9 (2003).

[45] Esso L. J., Politique économique et développement: dynamique des recettes du café et du cacao en Côte d'Ivoire. PED N¹0, CIRES, 19 (2008). 
[46] Eldin M., Le climat. In : Le milieu naturel de la Côte d'Ivoire. Mémoire ORSTOM, 50, Paris France, Pp 73108 (1971).

[47] Declert C., Manuel de phytopathologie maraîchère tropicale : cultures de Côte d'Ivoire, 333 (1990).

[48] Anonyme., Source des données de SODEXAM (Société d'exploitation de développement aéroportuaire aéronautique météo), Station de Daloa, (2017).

[49] Koffié-bikpo C. Y. \& Kra K. S., La région du haut-Sassandra dans la distribution des produits vivriers agricoles en Côte d'Ivoire, Revue de Géographie Tropicale et d'Environnement. (2), 8 (2013).

[50] Perraud A., Les sols. In Le milieu naturel de la Côte d'Ivoire. Mémoires ORSTOM N ${ }^{\circ}$ 50, ORSTOM, Paris, France, pp 265-391, (1971).

[51] Lecomte P., Place et intégration de l'arbre dans l'exploitation agricole ivoirienne du Centre-Ouest. Cas de la région d'Oumé. Mémoire de fin d'étude CNEARC, Montpellier, France. Pp.109 (1990).

[52] Aké Assi L., Flore de la Côte d'Ivoire : étude descriptive et biogéographique, avec quelques notes ethnobotaniques. (Tome I, II et III), 1205 (1984).

[53] Gala Bi T. J., Bohoussou N. Y., Akotto O. F., Yao K. A., Impact des arbres associés sur l'exploitation cacaoyère dans les zones de transition forêt-savane : cas de M'brimbo (Centre-Sud de la Côte d'Ivoire), European Scientific Journal. 13(1), 18 (2017).

[54] Tondoh J. E., N'Guéssan K. F., Guéi A. M., Sey B., Koné A. W., Gnessougou N., Ecological changes induced by full-sun cocoa farming in Côte d'Ivoire, Global Ecology and Conservation. (3), 20 (2015).

[55] Oke D. O. and Odebiyi K. A., Traditionnal cocoa based agroforests and forest species conservation in Ondo State, Nigeria, Agriculture, Ecosystems and Environment. (122), 6 (2007).

[56] Zapfack L., Engwald S., Sonké B., Achoundong G. \& Madong B. A., The impact of land conversion on plant biodiversity in the forest zone of Cameroon, Biodiversity and Conservation. (11), 14 (2002).

[57] Kouadio N. K. C., Potentiel de régénération des espèces ligneuses préservées dans les agrosystèmes cacaoyers : cas du village de Djèkro (Centre-Ouest, Côte d'Ivoire). Mémoire de Master à l'Université Jean Lorougnon Guédé Daloa. Côte d'Ivoire. pp. 56 (2018).

[58] Piba S. C., Apport de la flore naturelle dans la vie de la population d'une région cacaoyère en Côte d'Ivoire : cas du département d'Oumé. Mémoire du Diplôme d'Etude Approfondie à l'Université de Cocody. (Abidjan, Côte d'Ivoire). pp. 64 (2009).

[59] Kokou K. \& Caballé G., Les îlots forestiers de la plaine côtière togolaise, Bois et Forêts des Tropiques. 263 (1), 12 (2000).

[60] Vroh B. T. A., Evaluation de la dynamique de la végétation dans les zones agricoles d'Azaguié (Sud-est, Côte d'Ivoire). Thèse Doctorat, UFR Biosciences, Université Cocody, (Abidjan, Côte d'Ivoire). pp. 208 (2013).

[61] Diomandé V. P. A., Importance de la flore préservée en cacaoculture dans la vie de la population de la localité de Djêkro (Centre-Ouest de la Côte d'Ivoire). Mémoire de Master, Agriculture et Foresterie, Université Jean Lorougnon Guédé Daloa (Côte d'Ivoire). pp. 61 (2018).

Citation: Boko Brou Bernard, et.al., " Farmers Influence on Plant Diversity Conservation in Traditional Cocoa Agroforestry Systems of Côte D'Ivoire" International Journal of Research Studies in Agricultural Sciences (IJRSAS), 2020; 6(12), pp. 1-11, https://doi.org/10.20431/2454-6224.0612001

Copyright: $\bigcirc 2020$ Authors. This is an open-access article distributed under the terms of the Creative Commons Attribution License, which permits unrestricted use, distribution, and reproduction in any medium, provided the original author and source are credited. 